\title{
DETERMINANTS OF HOUSEHOLDS' WILLINGNESS TO PAY FOR WATER AND ELECTRICITY IN MOLETJIE UNDER AGANANG MUNICIPALITY, LIMPOPO PROVINCE, SOUTH AFRICA
}

\author{
Mmaphuti Andrias Nkoana ${ }^{1}$, Machuene Sharlyn Cholo ${ }^{1 凶}$, \\ Jan Johannes Hlongwane ${ }^{1}$, Abenet Belete ${ }^{1}$ \\ ${ }^{1}$ University of Limpopo, South Africa
}

\begin{abstract}
The purpose of this paper was to profile the socioeconomic characteristics of household members and determine the factors affecting households' willingness to pay for water and electricity in Moletji, Aganang Local Municipality. Data was collected through key informant interviews, group discussions and household surveys from a total of 120 households using the probability proportional to sample size technique. The study showed that sampled households were dissatisfied with the unreliable water and electricity services ( $73 \%$ ) but were willing to pay to secure reliable water and electricity services $(87 \%)$. The empirical evidence from the ordered logit model indicates that the willingness to pay for water and electricity was significantly influenced by gender, number of adult equivalents, household size, total household expenditure, employment status, total household income above total average household income, sources of income and connection charges. These results have policy implications for government and other stakeholders in response to the dissatisfaction with water and electricity supply services. For example, research findings reinforce the need to focus on investing in building institutions, improving access to water, electricity and micro-credit, and create employment opportunities to improve the overall living standards. This paper recommends that collective action be taken by community members and policymakers to improve access to water and electricity at household level.
\end{abstract}

Keywords: households, willingness to pay, water, electricity, Aganang municipality, ordered logit model, Moletjie, new settlements

\section{INTRODUCTION, PROBLEM AND OPPORTUNITY STATEMENT}

The provision of reliable and adequate drinking water and electricity services in rural communities is of high imperative. South Africa is a highly populated country where most land is used for settlements rather than agriculture (Odiyo and Makungo, 2012). The challenges of poverty and unemployment are compounded by limited access to basic municipal services such as water, sanitation and electricity, as well as a lack of good quality social services (South African Treasury, 2011). In most developing countries, households heavily rely on wood fuel which impacts their health and socioeconomic status (Abdullah and Mariel, 2009). South African national and provincial government, together with all other key actors and stakeholders, collaboratively assist rural communities to improve their sustainable livelihoods.

$\bowtie$ Machuene Sharlyn Cholo, PhD, Department of Agricultural Economics and Animal Production, University of Limpopo, South
Africa, Private Bag X1 106, Sovenga, 0727, e-mail: machuenecholo053@gmail.com, https://orcid.org/0000-0003-2242-5491 
This includes basic services such as health services, poverty alleviation, food security, income distribution, reduced urban migration and further the provision of water and electricity (South African Treasury, 2011).

According to Atkinson (2015), many rural households do not have private water connections and, thus, are forced to queue to collect drinking water from public taps, public boreholes, wells, springs and rivers. Limpopo Province is an example of a predominantly rural and one of the poorest provinces in South Africa, with scarce water resources (Odiyo and Makungo, 2012). According to Hensher et al. (2005), water service interruptions can occur due to unexpected emergencies or system failures, as well as for planned maintenance. Therefore, the study further indicated that these interruptions affect the consumers' willingness to pay for water services since this problem is caused by capital investment and operations carried out by the suppliers. Extensive pollution in South Africa threatens the already scarce water resources by making the water less suitable for consumption (Odiyo and Makungo, 2012). In South Africa, there are different types of water and electricity billing. Some of the rural households depend on water from street taps whereas others buy it form their neighbors in time of shortages. Prepaid electricity is used in rural areas unlike in urban areas where the customers are served with a bill at the end of every month.

As households in many countries face changing levels of water availability and high electricity bills, there is a need to assess the value of varying service levels and prices in an effort to secure the provision of water and electricity in the society. However, little is known about how much households are willing to pay for specific service levels. According to Aganang Municipality (2016), there are many challenges associated with the supply of water and electricity in the municipality. Some of the challenges include drying up of boreholes, illegal connection, breakdown of water pumps, electrical equipment etc. Above all, water and electricity supply can be improved if households are able to pay for the services they receive from the government so that there can be enough government revenue to cover the costs incurred in supplying those services. However, due to the dependency syndrome, households tend to demand free water supply and electricity in rural areas; this makes the government unable to recover costs. Even though the South African government has taken a step to improve water and electricity supply, the rapid territorial expansion still puts a strain on the government since an additional household means an additional cost for the government.

\section{SCOPE OF THE STUDY}

\section{Purpose of the study}

The purpose of this study was to profile the socio-economic characteristics of household members and determine the factors affecting the households' willingness to pay for water and electricity in the new settlement of selected areas (Ga-Ramphele, Mokgohloa and Legodi) in Aganang Local Municipality. In addition, the study also assessed the households' perception of electricity and water services, and further evaluated the community's satisfaction with the current water and electricity supply services and the reasons behind it.

The objectives of this study are:

- to profile the socio-economic characteristics of household members in the new settlements of GaRamphele, Mokgohloa and Legodi, Aganang Municipality, Limpopo province;

- to determine the factors influencing the households' willingness to pay for water and electricity services in the new settlements of Ga-Ramphele, Mokgohloa and Legodi, Aganang Municipality, Limpopo province.

\section{Research question}

What are the factors influencing the households' willingness to pay for water and electricity in rural areas of Ga-Ramphele, Mokgohloa and Legodi, Aganang Municipality?

\section{Study area}

The study was conducted in the new settlements of GaRamphele, Mokgohloa and Legodi villages of Aganang local Municipality in Capricorn District, Limpopo Province. Limpopo Province is located in the northern part of South Africa. Aganang municipality is one of the five local municipalities found in Capricorn District. More than $80 \%$ of people in Aganang Municipality speak Sepedi as their first language. According to Aganang $\mathrm{Mu}-$ nicipality (2016), 7\% of households have piped water in their dwelling and $94.6 \%$ have access to electricity. The backlog arises due to post connection since new houses are built in different areas within the municipality. The study used the simple random sampling technique to 

electricity in Moletjie under Aganang municipality, Limpopo province, South Africa. J. Agribus. Rural Dev., 1(51), 43-50. http:// dx.doi.org/10.17306/J.JARD.2019.01143

select the respondents in three selected villages. Only the households located within the new settlements of the three selected areas were considered for the purposes of this study. Semi-structured questionnaires were used in order to gather relevant data on the households' willingness to pay for electricity and water services from the municipality. Data on the value that customers place on each attribute was gathered in order to determine the appropriate level of water and electricity services relative to price. The study considered household heads as the respondents since the household was chosen as the unit of analysis for this study.

\section{Sampling and sample size}

Data was collected over a period of four weeks from midApril to mid-May 2017 using a team of five enumerators who speak the local Pedi language. A list of households from the three selected villages was obtained from the traditional leaders, headmen and the ward councilor. From the three selected villages (Ga-Ramphele, Mokgohloa and Legodi), simple random selection was done to obtain a sample of 120 households based on probability proportional to size. The total number of households in new settlements for the three selected areas was 219, with Ramphele, Mokgohloa and Legodi consisting of 78, 93 and 48 households, respectively. Based on probability proportional to sample size, $36 \%, 42 \%$ and $22 \%$ of the total number of new settlement households were interviewed from Ga-Ramphele, Mokgohloa and Legodi (see Table 1). This implies that 43 household heads from Ga-Ramphele, 51 from Mokgohloa and 26 from Legodi were interviewed to form the targeted sample size of 120 households. More than a $10 \%$ proportional sample size was collected from the three selected areas.

Table 1. Sample size in the respective sites of Moletjie community, Aganang Municipality, Limpopo province

\begin{tabular}{lrcrc}
\hline Villages & $\begin{array}{c}\text { Popula- } \\
\text { tion }\end{array}$ & $\begin{array}{c}\text { House- } \\
\text { hold } \\
\text { numbers }\end{array}$ & $\begin{array}{c}\text { Sample } \\
\text { size }\end{array}$ & Percentages \\
\hline Ramphele & 813 & 78 & 43 & $(43 / 120 \cdot 100=36 \%)$ \\
Mokgohloa & 1300 & 93 & 51 & $(51 / 120 \cdot 100=42 \%)$ \\
Legodi & 729 & 48 & 26 & $(26 / 120 \cdot 100=22 \%)$ \\
Total & 2842 & 219 & 120 & \\
\hline
\end{tabular}

Source: own calculation based on survey data (2017).
On average, the sample represents $18 \%$ of the total number of households in the selected areas.

\section{Empirical data analysis}

Descriptive statistics was applied to identify and describe socio-economic and demographic factors which determine the household users' preferences regarding the ways to reduce power outages and water supply interruptions. Data was analyzed using the Statistical Package for Social Science (SPSS) software version 22.0. Considering the discrete nature and ordinal ranking of the WTP variable, an ordered logit regression was applied, which is the most appropriate choice in studying the issue of ordinal ranking of the WTP variable (Greene, 2014). The model is set up around a latent regression that begins with the following equation:

$$
Y^{*}=X^{\prime} \beta+e
$$

where $Y$ is unobserved, and what can be observed is:

$$
Y_{\mathrm{i}}= \begin{cases}0 & \text { if } y \leq \mu_{1} \\ 1 & \text { if } \mu_{1} \leq \mathrm{y} \leq \mu_{2} \\ 2 & \text { if } \mu_{2} \leq \mathrm{y} \leq \mu_{3} \\ \ldots & \cdots \cdots \\ \mathrm{J} & \text { if } \mu_{\mathrm{J}-1} \leq \mathrm{y}\end{cases}
$$

\section{Descriptive results and discussions}

This section descriptively analyzes and discusses the results of the field survey carried out in selected areas of Moletjie community (Ga-Ramphele, Mokgohloa and Legodi) over a period of four weeks from mid-April to mid-May 2017. Table 2 below shows descriptive summary results of factors affecting the willingness to pay for water and electricity supply services.

The results presented in Table 2 above show that the average number of rooms in the new settlements of sampled households is four (4), and the households comprise six (6) members on average. The employment status of household heads was recorded to determine the impact of this variable on the sampled household's willingness to pay for water and electricity services received from the municipality. It was also estimated that about $53 \%$ of the sampled household heads are unemployed, $30 \%$ are permanent workers, $9 \%$ are temporary workers, and $8 \%$ are contract workers. Their average age is 38 years, including both male- (96) and female- (24) headed households. The relatively high proportion of unemployed household heads gives an indication of the 
Nkoana, M. A., Cholo, M. S., Hlongwane, J. J., Belete, A. (2019). Determinants of households' willingness to pay for water and electricity in Moletjie under Aganang municipality, Limpopo province, South Africa. J. Agribus. Rural Dev., 1(51), 43-50. http:// dx.doi.org/10.17306/J.JARD.2019.01143

Table 2. Descriptive summary of variables

\begin{tabular}{lccccc}
\hline \multicolumn{1}{c}{ Variables } & Mean & Std. dev. & Min & Max & VIF \\
\hline Monthly total income & 2534 & 27,394 & 1350 & 33,500 & 3.4351 \\
Highest education level & 11.5920 & 3.3170 & 0 & 16 & 0.0002 \\
Age & 37.6337 & 12.1576 & 19 & 78 & 0.0086 \\
Number of rooms & 4.2090 & 2.2099 & 1 & 15 & 0.0002 \\
Household size & 5.5693 & 2.5369 & 1 & 15 & 5.6101 \\
Years of stay & 3.8384 & 1.8819 & 3 & 8 & 0.2104 \\
Married & 0.7822 & 0.4129 & 0 & 1 & 9.3932 \\
Unemployed & 0.0693 & 0.2540 & 0 & 1 & 0.0001 \\
Gender & 0.4356 & 0.4959 & 0 & 1 & 4.5382 \\
Engage in farming & 0.6436 & 0.4790 & 0 & 1 & 6.2463 \\
Own home & 0.5842 & 0.4930 & 0 & 1 & 8.2774 \\
Household head & 0.5644 & 0.4959 & 0 & 1 & 6.1295 \\
Adult equivalent & 3 & 0.0676 & 1 & 4 & 4.2210 \\
\hline
\end{tabular}

Source: own calculation based on survey data (2017).

time available to fetch water and reflects the low opportunity cost of rural unskilled labor and the low probability of willingness to pay. The greatest area of land size operated by sampled household heads was 6 ha with an average of 0.94 ha. Economic, cultural and social heterogeneity was observed among households in terms of access to endowments such as land, labor and capital, motivations and skills and income generation activities (Barrett et al., 2005).

The results show that all of the sampled households of the new settlement in selected areas were combined. It was also revealed that over a quarter of the sampled households, which depict up to $27.5 \%$ of the residents, were satisfied with the current water and electricity supply services, whilst $72.5 \%$ of the residents were dissatisfied. About $40 \%$ of the sampled households reported to experience lack of water and poor electricity services as well as lack of water standpipes in their respective homes. This lack of water was reported to promote poor sanitation of about $8 \%$ of the sampled households which can be ascribed to poor maintenance of water facilities in $12 \%$ of the selected study areas. The reasons for the dissatisfaction with the current water service are outlined: most residents complained of poor services and some residents said that there was no water at prime time where most of them were at home after arriving from work. For the households satisfied with the current water services $(27.5 \%)$, the reason was that their homes were located on the downward slope and hence water services were always available. It can be deduced that the municipality should install pipes in all households without water connection. Employment incomes and childsupport grants were the most important non-agricultural income sources for over $60 \%$ of the respondents. However, the results showed that self-employment incomes $(5 \%)$, old age pensions $(12.5 \%)$, disability grants $(1.7 \%)$ and remittances (15.8\%) are important sources of income. Nearly all sampled households have a source of income but differ subsequently in the levels of incomes and education. To clarify this, sampled households were also asked whether, and how much per month, they are willing to pay for water and electricity supply services based on their current level of income they generate during that period. The higher the amount of money the household head is willing to pay, the higher the importance of water and electricity at household level.

Table 3 above shows a large proportion of sampled households who are willing to pay for water and 
Nkoana, M. A., Cholo, M. S., Hlongwane, J. J., Belete, A. (2019). Determinants of households' willingness to pay for water and electricity in Moletjie under Aganang municipality, Limpopo province, South Africa. J. Agribus. Rural Dev., 1(51), 43-50. http:// dx.doi.org/10.17306/J.JARD.2019.01143

Table 3. Proportion of the willingness to pay a premium for water and electricity supply services

\begin{tabular}{lcc}
\hline $\begin{array}{c}\text { Categories of premium payment } \\
\text { (ZAR/month) }\end{array}$ & Frequency & $\begin{array}{c}\text { Percentage } \\
(\%)\end{array}$ \\
\hline$Y=0$ (not willing to pay) & 16 & 13 \\
$0<Y \leq 250$ & 30 & 25 \\
$250<Y \leq 500$ & 34 & 28 \\
$500<Y \leq 750$ & 20 & 17 \\
$750<Y \leq 1000$ & 13 & 11 \\
$Y>1000$ & 07 & 6 \\
Total & 120 & 100 \\
\hline
\end{tabular}

Source: own calculation based on survey data (2017).

electricity supply services. About $87 \%$ of sampled households are willing to pay whilst $13 \%$ are not. However, the payment differs across households based on their level of income. This suggests that both maleheaded and female-headed households in the study area are highly dependent on water and electricity for their daily livelihoods. About $6 \%$ of households sampled are willing to pay for water and electricity supply services more than ZAR 1,000 per month. This indicates that water and electricity are highly essential at household level in the three study areas.

\section{Empirical model results}

This section presents the results of the ordered logit model and discusses the variables that explain the households' willingness to pay for water and electricity supply services in Moletjie community. Table 4 below provides the empirical results of the ordered logit model, showing the socio-economic characteristics and other contextual variables that influence the dependence of rural people on water and electricity.

The dependent variable in the empirical estimation is the expressly chosen premium amount of the willingness to pay for water and electricity supply services by sampled households (which differed from one household to another). The explanatory variables were chosen based on data availability, economic theory and literature. The set of explanatory variables differs across coefficient parameters and in terms of marginal effects. The model was tested for multicollinearity and heteroscedasticity. Multicollinearity was checked by examining variance
Table 4. Estimation results of the ordered logit model

\begin{tabular}{lccc}
\hline \multicolumn{1}{c}{ Variable } & $\begin{array}{c}\text { Estimated } \\
\text { coefficient }\end{array}$ & $\begin{array}{c}\text { Standard } \\
\text { error }\end{array}$ & Z-ratio \\
\hline Constant & -9.900 & 0.951 & -10.40 \\
Age & 0.171 & 0.553 & 0.581 \\
Edu & 0.006 & 0.112 & 0.052 \\
Gender & $1.10^{* *}$ & 0.250 & 4.41 \\
Adult equivalent & $0.78^{* *}$ & 0.375 & 2.09 \\
Household size & $0.26^{* * *}$ & 0.105 & 2.93 \\
Household expenditure & $-0.42^{* *}$ & 0.190 & 2.20 \\
Employment status & $0.81^{* * *}$ & 0.158 & 5.10 \\
Household income above & $0.60^{* * *}$ & 0.212 & 2.87 \\
average household income & & & \\
Sources of income & $0.002^{* *}$ & 7.067 & 2.71 \\
Connection charges & $0.60^{*}$ & 0.369 & 1.63 \\
\hline
\end{tabular}

Number of observations $=120$

Wald $\chi^{2}$ statistic $=68.42 * * *$

Log likelihood $=-64.94$

Pseudo- $\mathrm{R}^{2}=0.71$

Deviance $\chi^{2}(240)=124.48$ and Pearson $\chi^{2}(254)=147.11$

( significant level $=1.000)$

Classification accuracy (correctly predicted)

$*, * *, * * *$ represent significance at $10 \%, 5 \%$ and $1 \%$, respectively.

Source: own calculation based on survey data (2017).

inflation factors. An OLS model was run to test for multicollinearity using the variance inflation factor (VIF). The VIFs for all variables are less than 10 with an average of 4.05 , indicating that multicollinearity is not a serious problem in this model (Gujarati and Porter, 2009). An OLS model was also run to test for heteroscedasticity using the Breusch-Pagan/Cook-Weisberg test. There was no heteroscedasticity since the calculated $\chi^{2}$ value (1.97) was smaller than the tabulated $\chi^{2}$ value (3.38) at the $5 \%$ significance level and one degree of freedom. The goodness-of-fit of the model is relatively high. The estimated Deviance $\chi^{2}$ of 124.48 and Pearson $\chi^{2}$ of 147.11 with 240 degrees of freedom (df) show statistical significance relatively well above the $5 \%$ level, suggesting that the ordered logit model adequately fits the data and is consistent with the ordered logit model assumptions. The estimated Wald $\chi^{2}$ statistic of 68.42 indicates that the likelihood ratio statistics are highly statistically significant $(p<0.001)$. The empirical evidence from this 
study indicates that the willingness to pay for water and electricity by sampled households is significantly influenced by gender of the household head, number of adult equivalents, household size, total household expenditure, employment status, total household income above average household income, sources of income and connection charges. The parameter estimates of the ordered logit model provide only the direction of the effect of the independent variables on the dependent (response) variable; i.e. the estimates represent neither the actual magnitude of change nor the probabilities. The marginal effects or marginal probabilities are functions of the probability itself and measure the expected change in probability of a particular choice being made with respect to a unit change in an independent variable from the mean (Greene, 2014).

\section{Discussion of factors influencing the willingness to pay for water and electricity supply services}

The variable "adult equivalent" was used to determine the proxy for the availability of labor resources with respect to age within the households sampled. Higher age of rural adult members was assumed to be linked to greater indigenous knowledge of usable water and electricity and to a greater number of sources of income. As indicated before, the unit of analysis for this study was a household. However, for the availability of labor endowments in the household and income, "adult equivalent" was the reference unit (Atkinson, 2015). Thus, working rates of household members were converted into adult equivalent. The number of adult equivalents in a household was determined by means of average working rates in terms of different ages in the households.

No. of adult equivalent $=$ No. of male adults (aged $15-55$ years) $+0.84 \times$ No. of female adults (aged 15-55 years) $+0.24 \times$ No. of male children (aged 6-9 years) + $0.19 \times$ No. of female children (aged 6-9 years) +0.84 $\times$ No. of male children (aged 10-15 years) $+0.66 \times$ No . of female children (aged 10-15 years) $+0.61 \times$ No. of male adults (aged $>55$ years) $+0.47 \times$ No. of female adults ( $>55$ years).

The coefficient estimates for adult members is positive and statistically significant at a $10 \%$ level of significance, indicating that the likelihood of paying for water and electricity increases as the number of adult members increases. This implies that the household's labor endowment has the largest effect on its willingness to pay for water and electricity in the selected study areas. Deressa et al. (2009) reported that larger households are forced to divert part of their labor force to off-farm activities to generate more income so as to influence their consumption pressure. The negative marginal effect for "adult equivalent" of the household head shows that a unit increase in this variable reduces the probability of the willingness to pay by $0.5 \%$. The household head's gender is an important socio-economic factor influencing the ability of the rural households' willingness to pay for water and electricity services. Various studies have shown that gender is an important variable influencing the adoption decision at farm level (Dolisca et al., 2006; Nhemachena and Hassan, 2007). The sign of the coefficient estimate for gender (GENDER) of the household head is positive and statistically significant at a $10 \%$ level of significance. This implies that the likelihood of the willingness to pay for water and electricity is higher for male-headed households. The negative marginal effect for the gender of the household head shows that a unit increase in this variable reduces the probability of the willingness to pay by $0.4 \%$.

The coefficient estimates and marginal effects for higher levels of household income above average household income are positive and highly statistically significant at $1 \%$. The positive coefficient shows that the households sampled which had an income above the mean are statistically more likely to pay for water and electricity. This also suggests that the likelihood of paying for water and electricity, as opposed to not paying, increases with an increase in average household incomes. This implies that a unit increase in the household's average income increases the probability of willingness to pay by $0.2 \%$. These findings are similar to the results by Hassan and Nhemachena (2008) who demonstrated a positive relationship between the level of adoption in agricultural production and the availability of income. Households with above-average incomes are relatively in a better position to pay for water and electricity and rely less on natural resources for sustainable welfare. Deressa et al. (2009) showed that the availability of sufficient income in rural households eases the cash constraints and allows households to purchase various inputs. This result could perhaps be ascribed to a low unemployment rate and the dependence on governmental grants (old-age pension, child and disability support grants) in the study areas. 
The diversification of income sources has a positive relationship with the willingness to pay for any type of commodity at household level. Evidence from empirical results shows that off-farm incomes and employment income generated by the household head have a positive impact on the sampled households' willingness to pay for water and electricity. These findings confirm prior expectations and support evidence from other studies showing that an increase in off-farm and employment income decreases the dependence on natural forest products (Hogarth, 2012) since households will use more productive inputs such as electricity instead of fuel wood. This implies that there is a greater capacity to make use of different available income sources, and to promote sustainable household food security and poverty alleviation. The parameter estimate for unearned income suggests that households generating more income from off-farm activities are less dependent on natural forest products, and therefore will turn more to electricity. The positive and statistically significant parameter estimate corresponding to employment income suggests that households generating more employment income are more dependent on water and electricity. The employment income of the household head showed highly statistical significance at $1 \%$, implying that the employed household heads' willingness to pay for water and electricity increases as employment income increases.

The coefficient estimate for connection charges is positive and statistically significant at $10 \%$. The positive coefficient shows that sampled households with more electrical equipment or charges are statistically more likely to pay for water and electricity. This also suggests that the likelihood of paying for water and electricity, as opposed to not paying, increases with an increase in the number of connection charges or appliances in the household. This implies that a unit increase in the number of electric appliances at the households sampled increases the probability of their willingness to pay. Therefore, there is enough evidence to say that rural households in the study areas are willing to pay for municipal water and electricity services even though they are constrained with lack of opportunities and institutional support.

The coefficient parameter for household size is positive and highly statistically significant at a $1 \%$ level of significance indicating that the likelihood of paying for water and electricity increases as the number of household members increases. This result is consistent with prior expectations since more members in the household will need to have more water and enough electricity for their livelihoods. This result implies that a unit increase in household size increases the probability of willingness to pay more for water and electricity services. The sign of the coefficient estimate for household expenditure of the household head is negative and statistically significant. This implies that the likelihood of the willingness to pay for water and electricity decreases with an increase in the household's total expenditure. The negative marginal effect for household expenditure of the household head shows that a unit increase in this variable reduces the probability of willingness to pay as opposed to not to pay. This estimated result can also be supported by the results of the analysis of household size and adult equivalent at household level which all proved to have a positive relationship with the willingness to pay for water and electricity services. However, surprisingly, there was a significant relationship between age and educational level of the household head. The results imply that there is no sufficient evidence to say that age and educational level of the household head influence the willingness to pay for water and electricity services.

\section{CONCLUSIONS, RECOMMENDATION AND IMPLICATIONS FOR POLICY}

The results of the ordered logistic regression model revealed that the differences in socio-economic factors and asset endowments were the main determinants of the willingness to pay for water and electricity supply services. Over a quarter of the households sampled, which depict up to $27.5 \%$ of the residents, were satisfied with the current water and electricity supply services, whilst $72.5 \%$ of the residents were dissatisfied. These results have policy implications for the government and other stakeholders in response to the dissatisfaction with water and electricity supply services in rural areas of South Africa. For example, research findings reinforce the need to focus on investing in building institutions, improving access to water and electricity and microcredit, and create employment opportunities within rural communities to improve the overall living standards. Furthermore, this might be useful in facilitating the transfer of rights and responsibilities for local resource management as a pathway towards poverty alleviation 
Nkoana, M. A., Cholo, M. S., Hlongwane, J. J., Belete, A. (2019). Determinants of households' willingness to pay for water and electricity in Moletjie under Aganang municipality, Limpopo province, South Africa. J. Agribus. Rural Dev., 1(51), 43-50. http:// dx.doi.org/10.17306/J.JARD.2019.01143

and sustainable welfare. Also, it could provide opportunities for empowerment and improved capabilities for sustainable livelihoods of societies dependent on natural resources. It can also serve as a critically important means to improve income and employment through streamlined resource management and better skills to access sufficient water and electricity at lower prices.

About $87 \%$ of the households sampled indicated that they will pay for the use of water and electricity supply services in their own households. This paper recommends that collective action be taken by community members and policymakers in addressing these issues so as to improve access to water and electricity at household level. There should be co-management between the community and government rather than government management alone. Collective action (such as by engaging district officers, private associations, traditional leaders, community members, community extension officers, local/regional governments) and networks among community members can facilitate access to information and even allow community members to participate in technology development. The most vulnerable and marginalized rural groups often lack access to resources (that is, either they have no access and/or when they have it, they face insecure property rights) and find participation in collective action too costly because of lack of time and resources. Government agencies need to change how they work with communities, becoming more conscious in their efforts to strengthen local management institutions and allowing more local decision-making. Therefore, awareness promotion on the different causes and consequences of scarcity of water and electricity should be initiated for the community.

\section{ACKNOWLEDGEMENTS}

The authors would like to acknowledge the support by University of Limpopo, enumerators and respondents who contributed to the success of this research study.

\section{REFERENCES}

Abdullah, S., Marie, L. P. (2009). Choice experiment study on the willingness to pay to improve electricity services. Bath: University of Bath.
Aganang Municipality (2016). Aganang Local Municipality Integrated Development Plan Draft IDP 2016/17. Retrieved May $15^{\text {th }} 2017$ from: www.aganang.gov.za

Atkinson, A. B. (2015). Income Distribution in OECD Countries, OECD Social Policy Studies, No. 18, Paris.

Barrett, C. B., Bezuneh, M., Clay, D., Reardon, T. (2005). Heterogeneous constraints, incentives and income diversification strategies in rural Africa. Quar. J. Int. Agric., 44(1), 37-60.

Deressa, T., Hassan, R., Alemu T., Yesuf, M., Ringler, C. (2009). Analyzing the Determinants of Farmers'Choice of Adaptation Methods and Perceptions of Climate Change in the Nile Basin of Ethiopia. IFPRI Discussion Paper 00798.

Dolisca, F., Carter, D. R., McDaniel, J. M., Shannon, D. A., Jolly, C. M. (2006). Factors influencing farmers 'participation in forestry management programs: A case study from Haiti. Forest Ecol. Manag., 236(2), 324-331.

Greene, W. (2014). Econometric Analysis. NewYork: Macmillan.

Gujarati, D. N., Porter, D. C. (2009). Basic Econometrics. An Introduction: Basic Ideas and Concepts Reading: Gujarati, ( $5^{\text {th }}$ ed., pp. 34-54).

Hassan, R., Nhemachena, C. (2008). Determinants of African Farmers' strategies for Adapting to Climate Change: Multinomial Choice Analysis. AfJARE, 2(1), 83-104.

Hensher, D., Shore, N., Train, K. (2005). Households' Willingness to Pay for Water Service Attributes. Env. Res. Econ., 32, 509-531.

Hogarth, N. J. (2012). The Role of Forest-Related Income in Household Economies and Rural Livelihoods in the Border-Region of Southern China. World Dev., 43, 111-123.

Kamanga, P., Vedeld, P., Sjaastad, E. (2008). Forest incomes and rural livelihoods in Chiradzulu District, Malawi. Ecol. Econ., 68, 613-624.

Nhemachena, C., Hassan, R. (2007). Micro-level Analysis of Farmers 'Adaptation to Climate Change in Southern Africa. IFPRI Discussion Paper No. 00714. Washington, D.C.: International Food Policy Research Institute.

Odiyo, J. O., Makungo, R. (2012). Water Quality Problems and Management in Rural Areas of Limpopo Province, South Africa. WIT Trans. Ecol. Env., 164, 135-146.

Statistics South Africa (2011). Census 2011. Retrieved May $14^{\text {th }} 2017$ from: www.statsa.gov.za

South African Treasury (2011). Local Government Budgets and Expenditure Review, Delivering Municipal Services in rural areas. Retrieved May 14 2017 from: www.treasury.gov.za 